\title{
Crocodile blood supplementation protects vascular function in diabetic mice
}

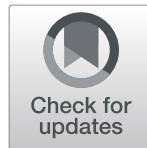

Chui Yiu Bamboo Chook', Francis M. Chen', Gary Tse', Fung Ping Leung ${ }^{1}$ and Wing Tak Wong ${ }^{1,2^{*}}$

\begin{abstract}
Cardiovascular disease is a major cause of mortality in diabetic patients due to the heightened oxidative stress and pro-inflammatory state in vascular tissues. Effective approaches targeting cardiovascular health for diabetic patients are urgently needed. Crocodile blood, an emerging dietary supplement, was suggested to have anti-oxidative and anti-inflammatory effects in vitro, which have yet to be proven in animal models. This study thereby aimed to evaluate whether crocodile blood can protect vascular function in diabetic mice against oxidation and inflammation. Diabetic $d b / d b$ mice and their counterparts $d b / m^{+}$mice were treated daily with crocodile blood soluble fraction (CBSF) or vehicle via oral gavage for 4 weeks before their aortae were harvested for endotheliumdependent relaxation (EDR) quantification using wire myograph, which is a well-established functional study for vascular function indication. Organ culture experiments culturing mouse aortae from C57BL/6 J mice with or without IL-1 $\beta$ and CBSF were done to evaluate the direct effect of CBSF on endothelial function. Reactive oxygen species (ROS) levels in mouse aortae were assessed by dihydroethidium (DHE) staining with inflammatory markers in endothelial cells quantified by quantitative polymerase chain reaction (qPCR). CBSF significantly improved deteriorated EDR in $\mathrm{db} / \mathrm{db}$ diabetic mice through both diet supplementation and direct culture, with suppression of ROS level in mouse aortae. CBSF also maintained EDR and reduced ROS levels in mouse aortae against the presence of pro-inflammatory IL-1 $\beta$. Under the pro-inflammatory state induced by IL-1 $\beta$, gene expressions of inflammatory cytokines were downregulated, while the protective transcripts UCP2 and SIRT6 were upregulated in endothelial cells. Our study suggests a novel beneficial effect of crocodile blood on vascular function in diabetic mice and that supplementation of diet with crocodile blood may act as a complementary approach to protect against vascular diseases through anti-oxidation and anti-inflammation in diabetic patients.
\end{abstract}

Keywords: Crocodile blood, Diabetes mellitus, Vascular endothelial function, Anti-oxidative, Anti-inflammatory

\footnotetext{
* Correspondence: jack_wong@cuhk.edu.hk

'School of Life Sciences, Faculty of Science, The Chinese University of Hong Kong, Shatin, NT, Hong Kong SAR

${ }^{2}$ State Key Laboratory of Agrobiotechnology, The Chinese University of Hong Kong, Hong Kong, China
}

(c) The Author(s). 2021 Open Access This article is licensed under a Creative Commons Attribution 4.0 International License, which permits use, sharing, adaptation, distribution and reproduction in any medium or format, as long as you give appropriate credit to the original author(s) and the source, provide a link to the Creative Commons licence, and indicate if changes were made. The images or other third party material in this article are included in the article's Creative Commons licence, unless indicated otherwise in a credit line to the material. If material is not included in the article's Creative Commons licence and your intended use is not permitted by statutory regulation or exceeds the permitted use, you will need to obtain permission directly from the copyright holder. To view a copy of this licence, visit http://creativecommons.org/licenses/by/4.0/. 


\section{Highlights}

- Daily oral crocodile blood supplementation for 5 weeks ameliorated endothelial dysfunction in $d b / d b$ diabetic mice through suppressing the overproduced reactive oxygen species (ROS).

- Direct action of improving endothelium-dependent relaxation (EDR) and lowering ROS level on mouse aortae were demonstrated using ex vivo organ culture experiments on mouse aortae.

- Vasoprotective effects observed against inflammation-induced endothelial dysfunction provides strong evidence and a possible mechanism for the beneficial effects of crocodile blood on vascular health in diabetes.

\section{Background}

One in ten people worldwide suffer from diabetes mellitus (Saeedi et al. 2019), and one in three type 2 diabetic patients has cardiovascular disease (Einarson et al. 2018). While currently used therapeutic strategies for diabetic patients focus mainly on lowering blood glucose levels, diabetes medications only modestly improve cardiovascular disease outcomes, without significantly reducing cardiovascular mortality in diabetic patients (Kelly 2009; Turnbull et al. 2009). Therefore, there is a need for new approaches to improve cardiovascular health in diabetes mellitus patients. In particular, suppression of reactive oxygen species (ROS) and inflammation were suggested to be a mechanism-based therapeutic approach due to its pivotal role in the pathology of diabetic cardiovascular disease (Giacco \& Brownlee 2010).

Crocodile blood, marketed as a dietary supplement since 2008 (Chaeychomsri et al. 2013), has been suggested to have a wide range of physiological benefits (Chook et al. 2021), including anti-oxidative (Jangpromma et al. 2018; Lueangsakulthai et al. 2018; Phosri et al. 2014, 2017; Theansungnoen et al. 2014), anti-inflammatory (Jangpromma et al. 2017; Kommanee et al. 2014; Lueangsakulthai et al. 2018; Pata et al. 2011; Phosri et al. 2014, 2017), anti-microbial (Aree et al. 2011; Hao et al. 2012; Kommanee et al. 2012; Merchant et al. 2011; Pata et al. 2007, 2011; Phupiewkham et al. 2018), anti-viral (Kozlowski et al. 2016), anti-tumor (Maijaroen et al. 2018; Maraming et al. 2018; Ou \& Ho 2016; Patathananone et al. 2015; Phosri et al. 2018), wound healing enhancing (Jangpromma et al. 2016; Pakdeesuwan et al. 2017) and anti-anemia (Chaeychomsri 2015) effects. Novel functional substances such as Leucrocins (Pata et al. 2011) and crocosin (Preecharram et al. 2010) were identified from crocodile blood. Crocodile blood has thus attracted growing attention and is anticipated to bring new hope to different fields of medications (Smith 2019).
We thereby hypothesized that crocodile blood may have protective effects on vascular endothelial function against diabetic damage through anti-oxidation and antiinflammation. Using endothelium-dependent relaxation (EDR) as an indicator (Versari et al. 2009), this study examined the effects of crocodile blood on endothelial dysfunction in $d b / d b$ diabetic mice, aiming to evaluate the potential of crocodile blood supplementation on improving vascular health in diabetic patients.

\section{Materials and methods \\ Preparation of crocodile blood soluble fraction}

Crocodile blood collected from farmed crocodiles in Thailand was first sterilized at high temperature, with further confirmation on the absence of virus or pathogens warranted. The blood was then freeze-dried, and ground into powder. Upon receival, the crocodile blood powder (HK JEBN Limited, HK) was dissolved in phosphate-buffered saline (PBS). The mixture was then centrifuged at $3900 \times \mathrm{g}$ for $15 \mathrm{mins}$ and filtered through a $0.22 \mu \mathrm{m}$ filter to obtain a clear pale-yellowish solution, noted as crocodile blood soluble fraction (CBSF) in this article. All the weight of CBSF in the doses (in vivo experiments) or concentrations (in vitro experiments) refer to the weight of dissolved freeze-dried crocodile blood powder.

\section{Animal models}

Animal experiments were performed on male type 2 diabetic $d b / d b$ mice lacking the gene encoding for leptin receptor from C57BL/KSJ background, the counterpart heterozygote $\mathrm{db} / \mathrm{m}^{+}$mice and C57BL/6 J mice, which were supplied by the Laboratory Animal Service Center (LASEC), the Chinese University of Hong Kong (CUHK), with the approval from the Animal Experimentation Ethics Committee, CUHK (Ref No. 18-243-MIS). Mice were kept in a temperature-controlled holding room $\left(22-24{ }^{\circ} \mathrm{C}\right)$ with a 12 -h light/dark cycle. Standard diet and water were provided ad libitum. All $d b / d b$ mice have established blood glucose level over $33.3 \mathrm{mmol} / \mathrm{dL}$ before they were randomly divided into 2 groups. $\mathrm{Db} / \mathrm{m}^{+}$ mice were also divided into 2 groups without any significant difference in body weight nor blood glucose. At 10 weeks of age, the $d b / d b$ and $d b / m^{+}$mice were treated with $25 \mathrm{mg} / \mathrm{kg}$ body weight/day CBSF for 4 weeks or vehicle (PBS) via oral gavage. Blood was collected into heparinized tubes after anesthetizing the mice before sacrifice.

\section{Basic parameters}

Glucose, total cholesterol, and triglyceride concentrations of the supernatant plasma from centrifuged blood were determined using Glucose LiquiColor ${ }^{\circ}$, LiquiColor ${ }^{\circ}$ Triglycerides and Cholesterol LiquiColor ${ }^{\circ}$ tests (Stanbio, 
Boerne, TX, USA) respectively as described in the provided protocols. Blood pressures were measured using the tail-cuff sphygmomanometer $\left(\mathrm{CODA}^{\circ}\right.$ High Throughput System, Kent Scientific Corporation, Torrington, CT, USA).

\section{Isometric force measurement}

After euthanizing the mice by carbon dioxide $\left(\mathrm{CO}_{2}\right)$ inhalation, thoracic aortae were rapidly removed and immersed in ice-cold oxygenated Krebs-Henseleit solution. Each aorta, with its perivascular adipose tissue removed, was cut into 2$\mathrm{mm}$ segments of aortic rings. Changes in isometric tension of the aortic rings were measured and recorded in the Multi Myograph System (Danish Myo Technology, Aarhus, Denmark) as previously described (Huang et al. 2003). Each aortic ring was mounted to one chamber on the Multi Myograph System using two wires and stretched to an optimal baseline tension of $3 \mathrm{mN}$. The aortic rings were allowed to equilibrate in the chamber for $60 \mathrm{mins}$ before the start of experiment. $60 \mathrm{mmol} / \mathrm{L} \mathrm{KCl-containing} \mathrm{Krebs} \mathrm{solution} \mathrm{was}$ added to induce contraction of the aortic rings, which were then rinsed by Krebs solution to restore the baseline tension. Following the contraction induced by $3 \mu \mathrm{mol} / \mathrm{L}$ phenylephrine (Phe), endothelium-dependent relaxation (EDR) was studied along the cumulative addition of acetylcholine (ACh) from $3 \times 10^{-9}$ to $1 \times 10^{-5} \mathrm{~mol} / \mathrm{L}$, which stimulates endothelial cells to produce the vasodilator nitric oxide (NO). The aortae were then incubated with $\mathrm{L}-\mathrm{N}^{\mathrm{G}}$-nitro-L-arginine methyl ester (L-NAME) to inhibit NO production by endothelial nitric oxide synthase (eNOS) in the endothelial cells. Endothelium-independent relaxation was then studied in a similar manner as EDR instead using cumulative addition of sodium nitroprusside (SNP) $\left(1 \times 10^{-9}\right.$ to $\left.1 \times 10^{-5} \mathrm{~mol} / \mathrm{L}\right)$, which donates NO directly to smooth muscle cells to induce vasodilation. Each experiment was performed on rings prepared from different mice in duplicates.

\section{Organ culture of mouse aortic rings}

Aortic rings were obtained as previously described and incubated with or without CBSF overnight in Dulbecco's Modified Eagle's Media (DMEM, Gibco, Gaithersberg, MD, USA) culture media with $1 \mathrm{~g} / \mathrm{L}$ glucose, $10 \%$ fetal bovine serum (FBS, Gibco), $100 \mathrm{IU} / \mathrm{mL}$ penicillin and $100 \mu \mathrm{g} / \mathrm{mL}$ streptomycin (Penicillin-Streptomycin, Gibco). Aortic rings from $d b / m^{+}$and $d b / d b$ mice were divided into 4 groups: $d b / m^{+}$alone, $d b / m^{+}+0.4 \mu \mathrm{g} / \mathrm{mL}$ CBSF, $d b / d b$ alone, $d b / d b+0.4 \mu \mathrm{g} / \mathrm{mL}$ CBSF. C57BL/6 J mouse aortae were separated into groups of control, 1 $\mathrm{pg} / \mathrm{mL} \mathrm{IL}-1 \beta$ and $1 \mathrm{pg} / \mathrm{mL} \mathrm{IL-} 1 \beta+0.2 \mu \mathrm{g} / \mathrm{mL}$ CBSF. All aortic rings were incubated overnight in a $\mathrm{CO}_{2}$ incubator at $37^{\circ} \mathrm{C}$. All experiments on cultured aortic rings were done in duplicates.

\section{Detection of intracellular reactive oxygen species by} dihydroethidium fluorescence

The 2-mm aortae were put into optimal cutting temperature compound (O.C.T.) (Tissue-Tek ${ }^{\circ}$ O.C.T. ${ }^{\mathrm{Tm}}$ Compound, Sakura Finetek Europe B.V., Alphen aan den Rijn, Netherland), which were then snap frozen in liquid nitrogen for embedding. The embedded aortae were cut into $5 \mu \mathrm{m}$-thick slides for staining with $5 \mu \mathrm{M}$ dihydroethidium (DHE) (Invitrogen, Waltham, MA, USA) staining solution, which is blue in the cytosol and turns red when oxidized and intercalated with the nucleus. The emission of red light was detected by confocal microscope (TCS SP8 MP, Leica, Wetzlar, Germany). The DHE-emitted light intensity $(605 \mathrm{~nm})$ was normalized by the autofluorescence area $(488 \mathrm{~nm})$ from each aortic ring. Any DHE detection was done on aortic rings from the same mouse in triplicates.

\section{Endothelial cell culture}

Mouse brain microvascular endothelial cells (mBMECs) (Angio-Proteomie, Boston, MA, USA) were cultured in DMEM (Gibco) with $4.5 \mathrm{~g} / \mathrm{L}$ glucose, 0.5\% FBS (Gibco), $100 \mathrm{IU} / \mathrm{mL}$ penicillin and $100 \mu \mathrm{g} / \mathrm{mL}$ streptomycin (Penicillin-Streptomycin, Gibco) at $37^{\circ} \mathrm{C}$ in a $\mathrm{CO}_{2}$ incubator, divided into groups of control, $1 \mathrm{pg} / \mathrm{mL} \mathrm{IL}-1 \beta$ and $1 \mathrm{pg} /$ $\mathrm{mL}$ IL- $1 \beta+0.2 \mu \mathrm{g} / \mathrm{mL}$ CBSF.

\section{Cell proliferation assay}

Equal number of mBMECs in $100 \mu \mathrm{L}$ culture medium were seeded into each well of 96-well plate and supplemented with $0.2-51.2 \mu \mathrm{g} / \mathrm{mL}$ of CBSF. After overnight incubation, $50 \mu \mathrm{L} /$ well Activated-XTT Solution (XTT Cell Proliferation Assay Kit, Manassas, VA, USA) was added, followed by reading the absorbance at $475 \mathrm{~nm}$ (specific absorbance) and $660 \mathrm{~nm}$ (non-specific absorbance).

\section{Quantitative polymerase chain reaction (qPCR)}

RNA was extracted from homogenized mBMEC samples using TRIzol (Invitrogen) reagent. RNA was converted into cDNA using PrimeScript ${ }^{\text {tm }}$ RT Master Mix (TaKaRa, Kyoto, Japan) on Veriti ${ }^{\text {Tix }}$ 96-Well Thermal Cycler (ThermoFisher Scientific, Waltham, MA, U.S.). Quantitative polymerase chain reaction (qPCR) experiments were performed on the CFX96 Touch $^{\text {Ti }}$ Real-time PCR Detection System (Bio-Rad Laboratories, Hercules, CA, USA) with QuantiNova SYBR Green PCR kit (Qiagen, Hilden, Germany). Relative expression levels of mRNAs were calculated in relative to $36 B 4$ as the housekeeping gene using the $2^{\wedge}(-$ Delta Delta $C(T))$ Method. Primers used for qPCR analysis are available upon request.

\section{Drugs and solutions}

IL-1 $\beta$ was purchased from PeproTech (Rocky Hill, NJ, USA). DHE was purchased from Abcam (Cambridge, $\mathrm{UK})$. Acetylcholine (ACh), L- $\mathrm{N}^{\mathrm{G}}$-nitro-L-arginine methyl 

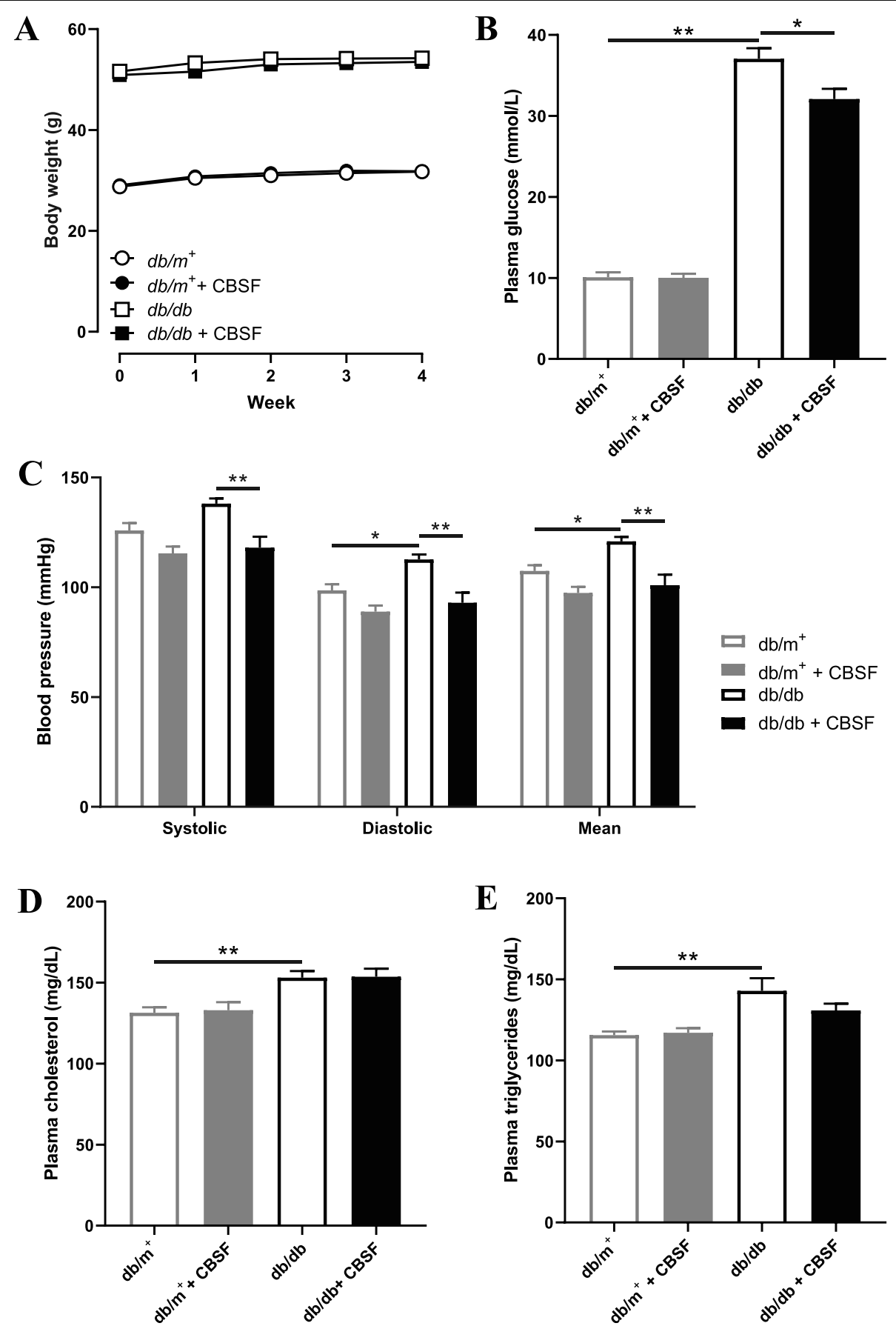

Fig. 1 Effects of oral CBSF treatment on the basic parameters of $d b / m^{+}$and $d b / d b$ mice. Body weight (a), plasma glucose level (b), systolic blood pressure, diastolic blood pressure, mean arterial pressure (c), plasma cholesterol (d) and plasma triglycerides (e) of $d b / \mathrm{m}^{+}$and $\mathrm{db} / \mathrm{db}$ mice treated or non-treated with CBSF $\left(25 \mathrm{mg} / \mathrm{kg} /\right.$ day) via oral gavage for 4 weeks. Data are presented in mean $\pm \mathrm{SEM} ; n=8,{ }^{*} p<0.05$ and ${ }^{* *} p<0.01$. CBSF, crocodile blood soluble fraction 

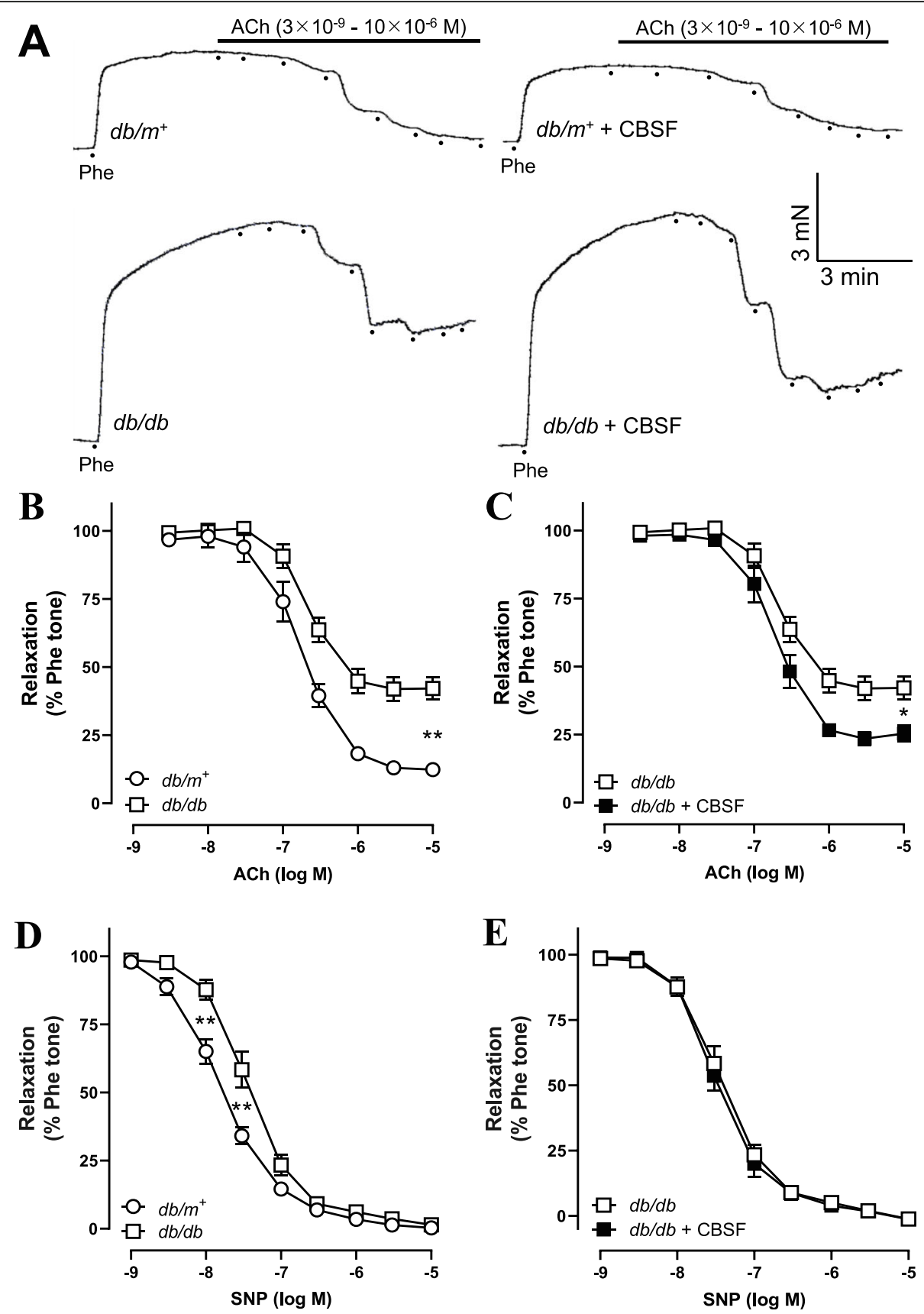

Fig. 2 Oral CBSF treatment improved the impaired endothelial-dependent relaxation (EDR) in $d b / d b$ mouse aortae. Representative tracings (a) with summarized data (b-c) of EDR measured by wire myograph in isolated aortae from $\mathrm{db} / \mathrm{m}^{+}$and $\mathrm{db} / \mathrm{db}$ mice with and without in vivo CBSF treatment $\left(25 \mathrm{mg} / \mathrm{kg} /\right.$ day). Summarized data of endothelium-independent relaxation of isolated aortae from $\mathrm{db} / \mathrm{m}^{+}$and $\mathrm{db} / \mathrm{db}$ mice treated or non-treated with CBSF $\left(\mathbf{d}\right.$-e). Data are presented in mean $\pm \mathrm{SEM} ; n=8,{ }^{*} p<0.05$ and ${ }^{* *} p<0.01$ relative to $d b / d b$. CBSF, crocodile blood soluble fraction; Phe, phenylephrine; ACh, acetylcholine; SNP, sodium nitroprusside 
ester (L-NAME), phenylephrine (Phe), and sodium nitroprusside (SNP) were purchased from Sigma-Aldrich Chemical (St Louis, MO, USA) and dissolved in doubledistilled water. Krebs-Henseleit solution is composed of (mmol/L): $119 \mathrm{NaCl}, 4.7 \mathrm{KCl}, 2.5 \mathrm{CaCl}_{2}, 1 \mathrm{MgCl}_{2}, 25$ $\mathrm{NaHCO}_{3}, 1.2 \mathrm{KH}_{2} \mathrm{PO}_{4}$, and 11 D-glucose.

\section{Statistical analysis}

Results were expressed as means \pm SEM for each group. Statistical significance was determined by two-tailed Student's $t$-test or one-way ANOVA when appropriate using GraphPad Prism software (Version 8.0, San Diego, CA, USA). A Bonferroni correction was performed for multiple comparisons. $P<0.05$ was regarded as statistically significant.

\section{Results}

\section{Safety and toxicity}

Prior to receival as powder in our laboratory, potential pathogens such as fungi, bacteria and virus in the crocodile blood samples were eliminated through high-temperature sterilization and lyophilization (Barba et al. 2017; Unger et al. 2009).
A dose-dependent trial was done on C57BL/6 J mice to evaluate the toxicity of crocodile blood (Suppl. Fig. 1). Five groups of mice were treated with different doses of crocodile blood: PBS (vehicle), 65, 130, 190 and $250 \mathrm{mg} / \mathrm{kg}$. All mice showed no observable behavioral changes. The body weight (Suppl. Fig. 1A) and non-fasting blood glucose (Suppl. Fig. 1B) of the mice also showed no significant difference between each group. Cytotoxicity on mBMECs was assessed by XTT assay. No significant difference in cell viability resulted from treatments of concentrations ranged from 0.2 to $51.2 \mu \mathrm{g} / \mathrm{mL}$ CBSF (Suppl. Fig. 1C).

\section{Basic parameters}

We first evaluated the effects of crocodile blood soluble fraction (CBSF) on the general metabolic health of the mice. Both $d b / m^{+}$and $d b / d b$ mice treated or non-treated with CBSF showed gradual weight gain over the 4-week oral treatment period with no significant difference between groups (Fig. 1a). Oral CBSF treatment for 4 weeks induced a subtle but significant drop in plasma glucose level in the $d b / d b$ mice, but not in $d b / m^{+}$mice (Fig. 1b). While the diastolic
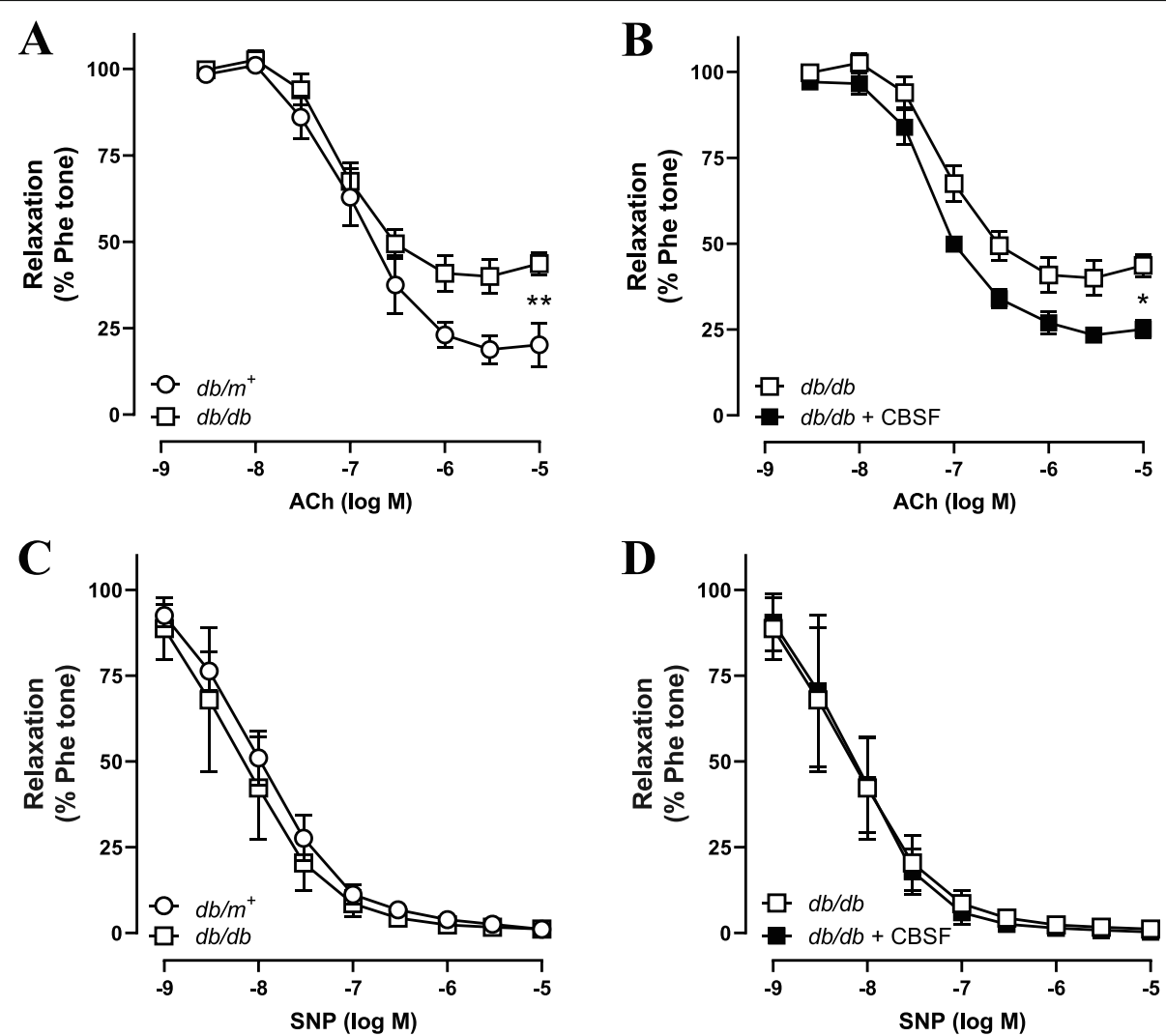

Fig. 3 Ex vivo CBSF incubation ameliorated the impaired EDR in $d b / d b$ mouse aortae. EDR measured by wire myograph in non-treated $d b / m^{+}$and $d b /$ $d b$ mice (a). Effect of ex vivo CBSF incubation on EDR in isolated aortae from non-treated $d b / d b$ mice (b). Effect of ex vivo CBSF incubation on endothelium-independent relaxation in isolated aortae from non-treated $d b / m^{+}$and $d b / d b$ mice (c-d). Data are presented in means \pm SEM; $n=3$ for $d b / m+, n=5$ for $d b / d b ;{ }^{*} p<0.05,{ }^{* *} p<0.01$. CBSF, crocodile blood soluble fraction; Phe, phenylephrine; ACh, acetylcholine; SNP, sodium nitroprusside 
and mean blood pressures were higher in $d b / d b$ mice than $\mathrm{db} / \mathrm{m}^{+}$mice, CBSF lowered the systolic, diastolic, and mean blood pressures significantly in the $d b / d b$ mice (Fig. 1c). In addition, CBSF had no significant effects on plasma cholesterol (Fig. 1d) nor triglyceride levels (Fig. 1e) in both $d b / m^{+}$ and $d b / d b$ mice.

\section{In vivo CBSF oral treatment improved endothelium-} dependent relaxation (EDR) in $d b / d b$ mouse aortae We then examined whether oral CBSF treatment effects endothelial function by wire myograph. The endotheliumdependent relaxation (EDR) induced by the addition of acetylcholine (ACh) was impaired in the $d b / d b$ control mice compared to the $d b / m^{+}$counterparts (Fig. 2a-b). The 4-week oral CBSF treatment improved the EDR in $d b / d b$ mouse aortae (Fig. 2a \& c), yet did not show a significant effect on the $\mathrm{db} / \mathrm{m}^{+}$mouse aortae (Fig. 2a). Following the inhibition of endothelial nitric oxide synthase (eNOS) by L-N ${ }^{G}$-nitro-L- arginine methyl ester (L-NAME), thus inhibiting the ability of endothelial cells to induce vasodilation, the total endothelium-independent relaxation induced by sodium nitroprusside (SNP) was found comparable among the groups, despite a difference in the initial relaxation between $d b / \mathrm{m}^{+}$ and $d b / d b$ mice (Fig. 2d-e).

\section{CBSF directly reversed impaired EDR in ex vivo cultured $d b / d b$ mouse aortae}

Our subsequent experiments investigated whether CBSF has a direct effect on endothelial function by incubating the $d b / d b$ and $d b / m^{+}$mouse aortae with or without CBSF overnight. While EDR was impaired in the $d b / d b$ group in relative to the $d b / m^{+}$group (Fig. 3a), CBSF incubation improved the EDR performance in $d b / d b$ mouse aortae (Fig. 3b), without affecting the endothelium-independent relaxation (Fig. 3c-d).
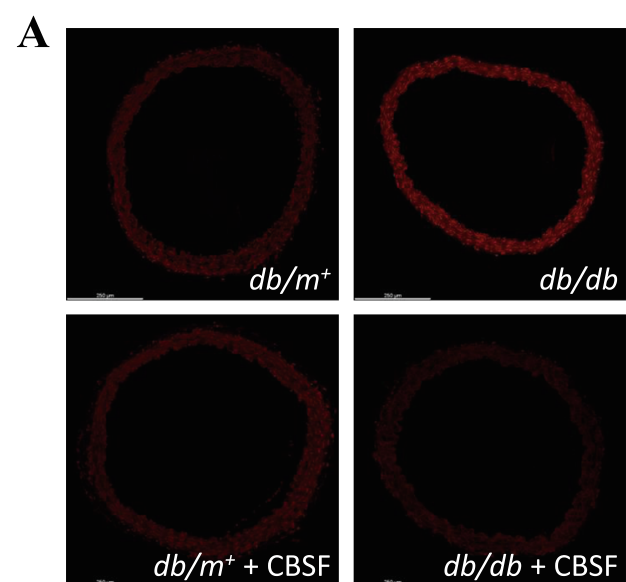

C
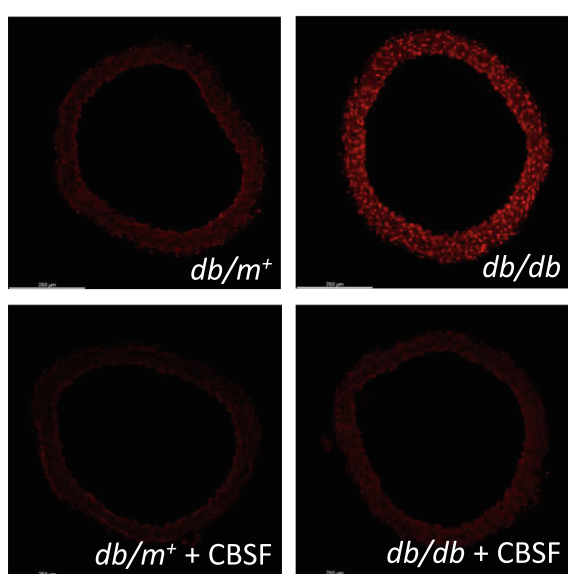

B

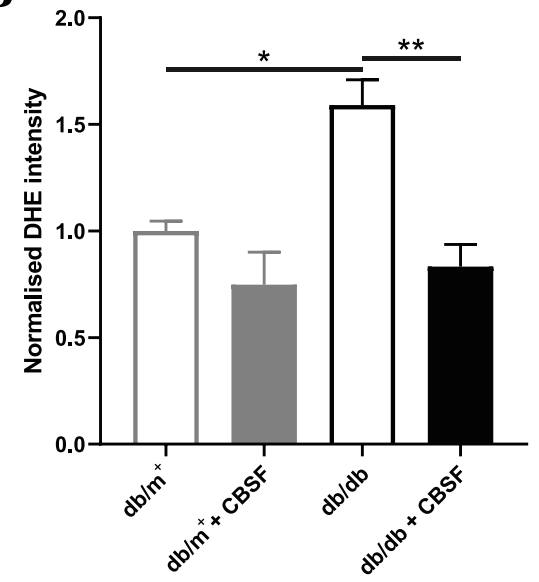

D

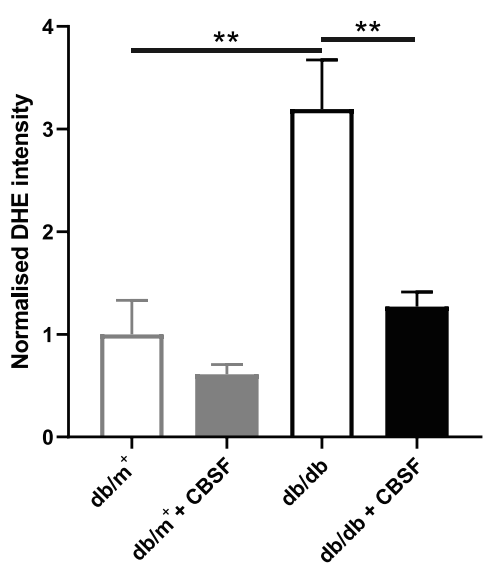

Fig. 4 CBSF suppressed the ROS level in $d b / d b$ mouse aortae both in vivo and ex vivo. Representative confocal images (a) with summarized data (b) of DHE stain intensity in isolated aortic rings from $\mathrm{db} / \mathrm{m}^{+}$and $\mathrm{db} / \mathrm{db}$ mice with and without in vivo CBSF treatment ( $25 \mathrm{mg} / \mathrm{kg} / \mathrm{day}$ ). Representative confocal images (c) and summarized data (d) of DHE stain intensity in isolated aortic rings from non-treated $\mathrm{db} / \mathrm{m}^{+}$and $\mathrm{db} / \mathrm{db}$ mice with and without ex vivo CBSF incubation $(0.4 \mu \mathrm{g} / \mathrm{mL})$. Data are presented in means $\pm \mathrm{SEM} ; n=5 ;{ }^{*} p<0.05,{ }^{* *} p<0.01$. CBSF, crocodile blood soluble fraction; ROS, reactive oxygen species; DHE, dihydroethidium 
CBSF reduced the ROS level in $d b / d b$ mouse aortae both in vivo and ex vivo

Oxidative stress is an important factor leading to endothelial dysfunction in diabetes (Giacco \& Brownlee 2010). As reflected by the total dihydroethidium (DHE) intensity, reactive oxygen species (ROS) levels were increased in $d b / d b$ mouse aortic rings as compared to $d b /$ $\mathrm{m}^{+}$control and were lowered by oral CBSF treatment (Fig. 4a-b). In addition, ex vivo CBSF incubation similarly reduced the heightened ROS levels in $d b / d b$ mouse aortic rings (Fig. 4c-d).

\section{CBSF directly reversed IL-1 $\beta$-induced EDR impairment in C57BL/6 J mouse aortae}

It is well established that inflammation plays an important role in mediating endothelial dysfunction in diabetes (Peiró et al. 2017; Tabit et al. 2010). Using the classical proinflammatory cytokine IL-1 $\beta$, we investigated whether CBSF protects endothelial function against inflammation (Peiró et al. 2016; Sprague \& Khalil 2009). Our results showed that EDR of mouse aortae from C57BL/6 J mice was impaired by IL-1 $\beta$ incubation (Fig. 5a), but reversed by co-incubation with CBSF (Fig. 5b). On the other hand, endotheliumindependent relaxation either incubated with or without IL$1 \beta$ was not affected by CBSF (Fig. 5c-d).

CBSF lowered the ROS level elevated by IL-1 $\beta$ in both normal mouse aortae and mouse brain microvascular endothelial cells (mBMECs)

Elevated ROS level was also observed in the IL-1 $\beta$ incubated mouse aortic rings, but was reduced by CBSF co-incubation (Fig. 6a-b). The high ROS level induced by IL- $1 \beta$ incubation was also lowered by CBSF coincubation in mBMECs (Fig. 6c-d).

\section{CBSF downregulated pro-inflammatory cytokines while upregulating protective gene expressions}

We further found that the pro-inflammatory cytokines, IL-6 (Fig. 7a), TNF- $\alpha$ (Fig. 7b), VCAM-1 (Fig. 7c) and MCP-1 (Fig. 7d), upregulated by IL-1 $\beta$ incubation, were reduced by CBSF. In addition, UCP2 (Fig. 7e) and SIRT6 (Fig. 7f) mRNA expression levels downregulated by IL-1 $\beta$ were also restored by CBSF co-incubation.
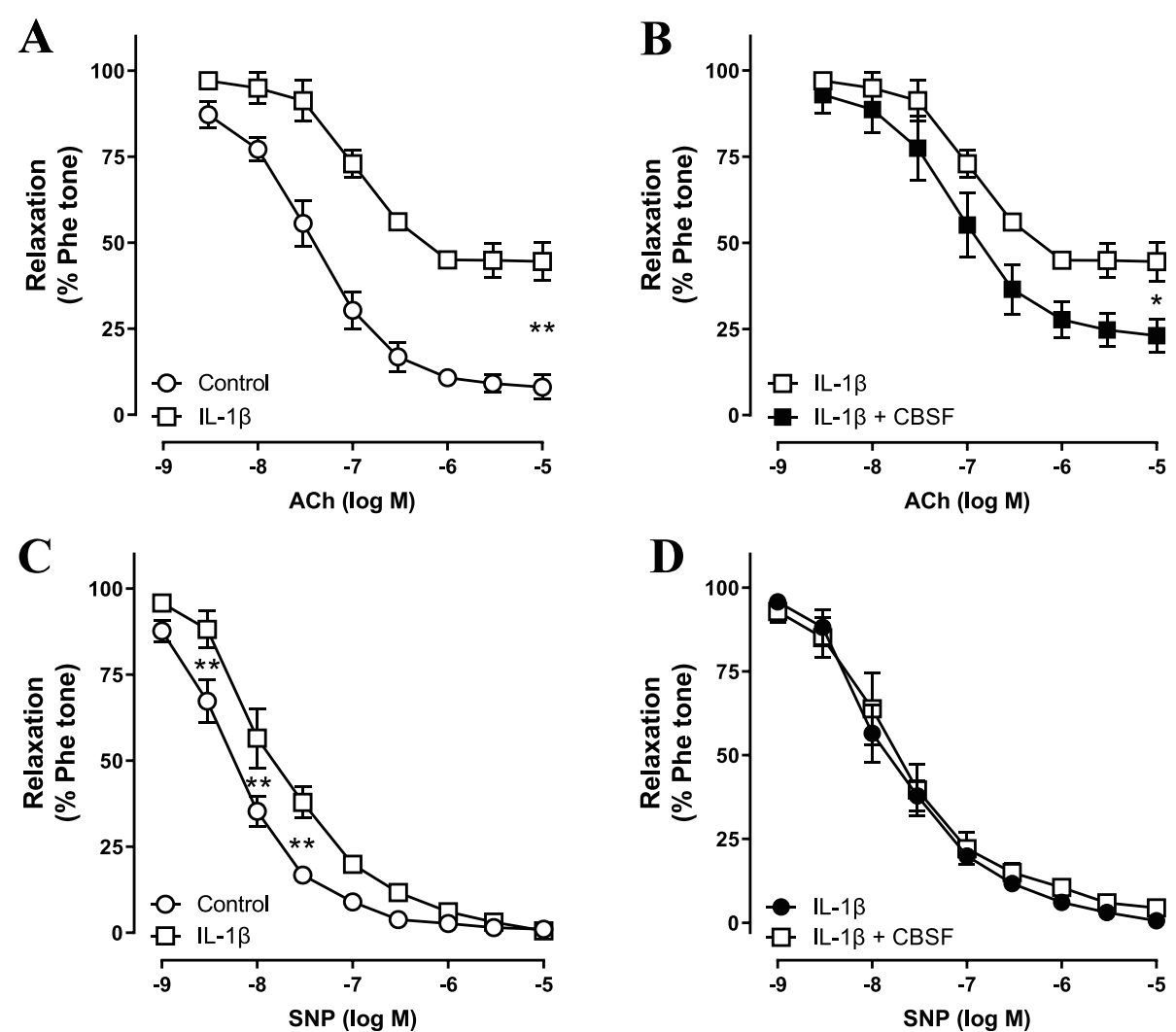

Fig. 5 Ex vivo CBSF co-incubation remedied IL-1 $\beta$-impaired EDR in C57BL/6 J mouse aortae. Effect of IL-1 $\beta$ (1 pg/mL) incubation on EDR of isolated aortae from C57BL/6 J mice (a). Effect of CBSF co-incubation on EDR of IL-1 $\beta$-treated aortae from C57BL/6 J mice (b). Effect of IL-1 $\beta$ incubation on endothelium-independent relaxation of isolated aortae from C57BL/6 J mice (c). Effect of CBSF co-incubation on endotheliumindependent relaxation of IL-1 $\beta$-treated aortae from C57BL/6 J mice (d). Data are presented in means \pm SEM; $n=5 ;{ }^{*} p<0.05,{ }^{* *} p<0.01$ compared to IL-1 $\beta$-treated group. CBSF, crocodile blood soluble fraction; Phe, phenylephrine; ACh, acetylcholine; SNP, sodium nitroprusside 

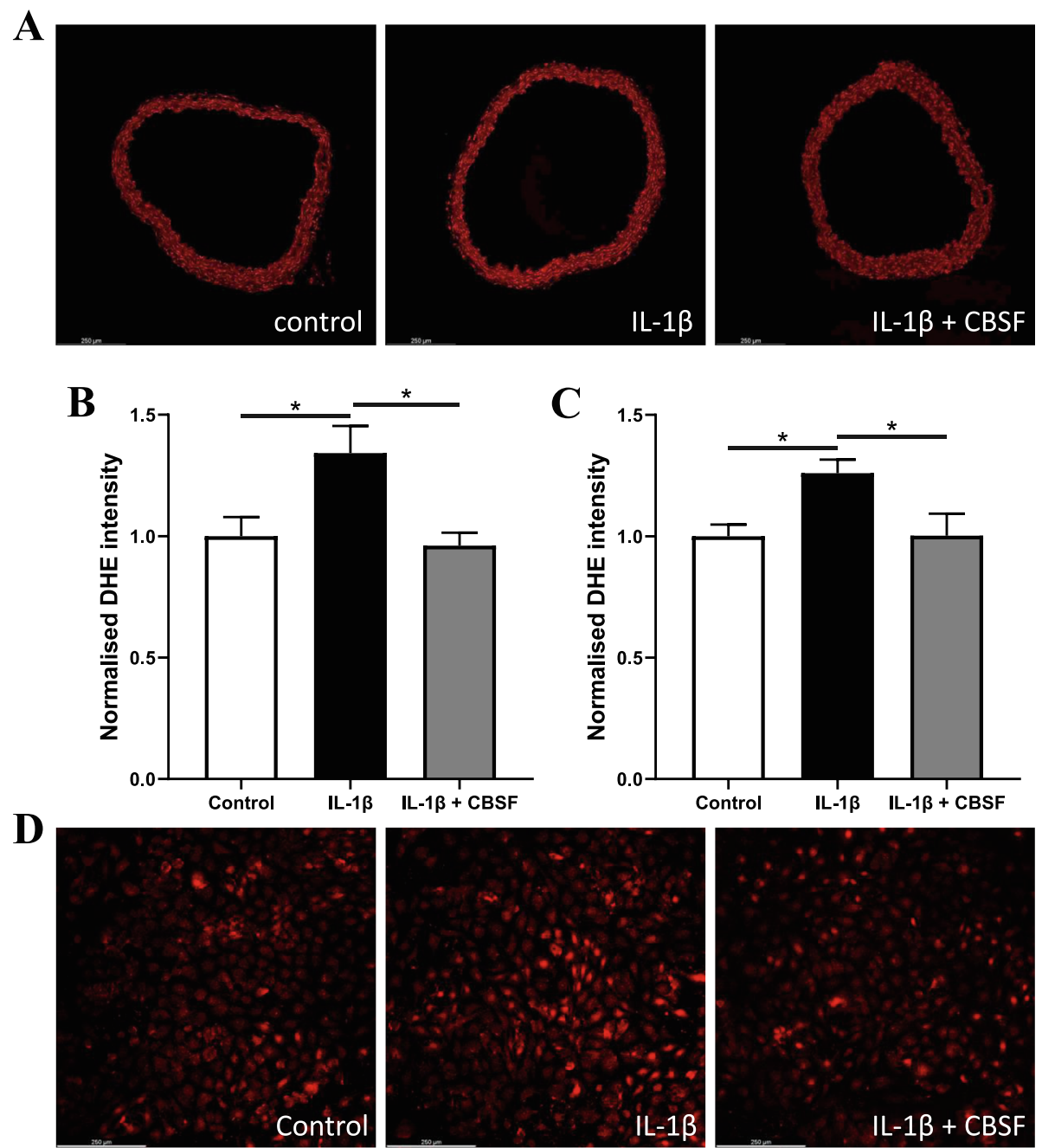

Fig. 6 CBSF co-incubation lowered the ROS levels exaggerated by IL-1 $\beta$ in both aortae and endothelial cells. Representative confocal images (a) and summarized data (b) of DHE stain intensity of C57BL/6 J aortic rings incubated with and without IL-1 $13(1 \mathrm{pg} / \mathrm{mL}) \mathrm{and} C B S F(0.2 \mathrm{mg} / \mathrm{mL})$. Summarized data $(\mathbf{c})$ and representative confocal images (d) of DHE stain intensity of mBMECs incubated with and without $\mathrm{LL}-1 \beta(1 \mathrm{pg} / \mathrm{mL})$ and $\operatorname{CBSF}(0.2 \mathrm{mg} / \mathrm{mL})$. Data are presented in means $\pm \mathrm{SEM} ; n=5$; ${ }^{*} p<0.05$. CBSF, crocodile blood soluble fraction; ROS, reactive oxygen species; DHE, dihydroethidium

\section{Discussion}

Endothelial dysfunction is an early manifestation and target for prevention of cardiovascular disease (Versari et al. 2009; Widlansky et al. 2003). Endothelial dysfunction refers to the inability of endothelial cells to maintain vascular homeostasis, which includes the regulation of vasoconstriction, vasodilation, inflammation and oxidative stress (Tabit et al. 2010). Vascular endothelial cells are particularly susceptible to hyperglycemic damage due to limited regulation of glucose transport rate and thus exaggerated glucose influx in high glucose conditions (Kaiser et al. 1993), explaining the especially high prevalence of cardiovascular disease in diabetic patients (Einarson et al. 2018).

In this study, $d b / d b$ mice lacking leptin receptor were used to evaluate the effects of crocodile blood on endothelial functions in type 2 diabetes mellitus. While the 4- week oral CBSF treatment may exert its effects either by direct or systemic influence through regulating blood glucose levels and blood pressure, the EDR improvement by direct CBSF incubation proved a direct protective effect on the endothelial function of CBSF against diabetic damage.

It is well established that upregulation of ROS plays a pivotal role in cardiovascular disease in diabetes (Giacco \& Brownlee 2010). Under hyperglycemia, the increased glucose influx leads to increased ROS production. The high oxidative stress not only uncouples eNOS, which further induces overproduction of ROS, but also reduces the bioavailability of $\mathrm{NO}$, which is responsible for vasodilation and anti-inflammation (Giacco \& Brownlee 2010; Kim et al. 2006). As a result, a cascade of proinflammatory markers including IL-1 $\beta$, IL- 6 and TNF- $\alpha$ 


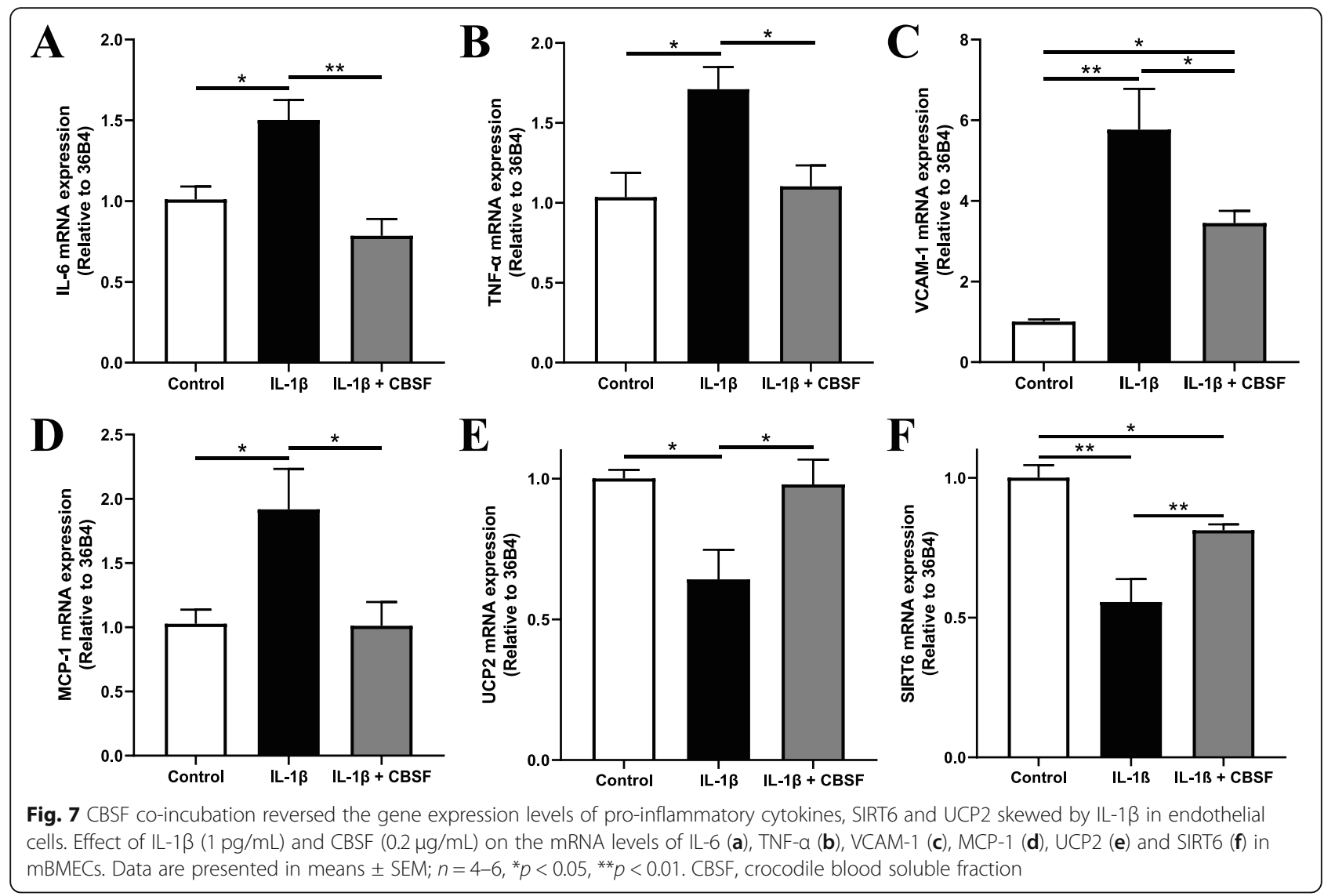

were upregulated, eventually leading to endothelial dysfunction, as displayed by EDR impairment (Versari et al. 2009). Our results consistently showed that ROS level increased in the $d b / d b$ mouse aortae was lowered by both in vivo and ex vivo CBSF treatment, indicating that CBSF may possibly protect endothelial function against hyperglycemic damage through ROS suppression.

Nevertheless, exertion of hyperglycemic damage requires pro-inflammatory conditioning (Azcutia et al. 2010; Lafuente et al. 2008; Peiró et al. 2016). It was found that hyperglycemia alone is not sufficient to induce EDR impairment, inflammation and ROS overproduction in blood vessels (Lafuente et al. 2008; Peiró et al. 2016). In the presence of pro-inflammatory IL- $1 \beta$, however, EDR is impaired, with both ROS production and inflammatory signaling exacerbated by high glucose concentrations (Peiró et al. 2016). The upregulation of VCAM-1 by hyperglycemia in endothelial cells also depends on the presence of IL-1 $\beta$ (Azcutia et al. 2010). Furthermore, IL-1 receptor antagonists were found to inhibit diabetic endothelial dysfunction (Vallejo et al. 2010). Thus, proinflammatory cytokines like IL- $1 \beta$ act as a prerequisite for hyperglycemic damage on endothelial function.

In our study, CBSF ameliorated the IL-1 $\beta$-induced EDR impairment and ROS overproduction in mouse aortae. More specifically, CBSF downregulated the oxidative stress, as well as inflammatory genes in endothelial cells. CBSF also upregulated UCP2 and SIRT6 gene expression in endothelial cells, which were suggested to have a protective role on the endothelial function (Tian et al. 2012; Xu et al. 2017). Thus, our results suggest that CBSF protects endothelial functions against inflammation, which may also be a possible mechanism underlying the protective effect of CBSF on endothelial function in diabetic mice.

Previous studies have shown that single-time oral treatment of crocodile blood lowered inflammatory cytokine production and increased the anti-oxidative enzyme levels in mouse models (Phosri et al. 2017; Phupiewkham et al. 2018). The doses used ranged from 62.5 to $250 \mathrm{mg} / \mathrm{kg}$ body weight and caused no observable toxicity to the experimental animals. According to a Thai Congress Report, the protein content of freeze-dried crocodile blood powder is $83.1 \%$ (Chaeychomsri et al. 2013). A number of short peptides were isolated from the leucocyte extract and hemoglobin of crocodile blood, and were suggested to possess anti-inflammatory and anti-oxidative effects in vitro (Lueangsakulthai et al. 2018; Phosri et al. 2017; Theansungnoen et al. 2014). However, the content of these peptides in crocodile 
blood and whether these peptides can also exert the same effects in vivo have not been revealed.

To the best of our knowledge, our study is the first long-term experiment to discover the vasoprotective effects of crocodile blood in vivo. However, given that our study primarily aimed to evaluate the effects of the available crocodile blood supplement on vascular function in $d b / d b$ mouse model, our results have two major limitations. First, detailed molecular mechanisms regarding the effects observed were not identified. Second, the responsible active components in crocodile blood require further investigations. A number of novel peptides identified in crocodile blood were suggested to possess antioxidative properties in vitro (Pata et al. 2011; Phosri et al. 2017; Theansungnoen et al. 2014), not to mention the many yet to be discovered. Whether these antioxidative peptides contribute to the in vivo vasoprotective effects described in this article is anticipated to be verified in future studies. It is also very likely that multiple active components collaboratively contribute to the described effects through different molecular pathways.

In addition to the previously suggested antiinflammatory, anti-oxidative, anti-microbial, anti-viral, anti-tumor, anti-anemia, and wound healing enhancing effects, our data indicated that crocodile blood may also protect vascular functions in diabetic patients. Although how the active substances in crocodile blood are digested, absorbed, and processed in the body requires further investigations, this study highlights the presence of vasoactive substances in crocodile blood, and acts as a first step in developing a novel vasoprotective medication or supplementation for diabetic patients. In view of the recent increased incidence of zoonotic diseases in humans such as SARS-CoV-2 and bird flu, further characterization of crocodile blood is needed to confirm the absence of virus and any possible pathogens.

\section{Conclusion}

Our results indicated that CBSF improved vascular endothelial function both in vivo and ex vivo in $d b / d b$ diabetic mice, possibly through ROS suppression. The positive effects also applied to IL-1 $\beta$-induced inflammation model, with downregulation of pro-inflammatory genes and upregulation of beneficial genes, which may explain how CBSF protects endothelial health in diabetic condition. Although verification of the exact mechanistic pathways requires further study, our study provides insights to the further identification of vasoprotective substances in crocodile blood, which can potentially be developed into a novel medicinal approach for diabetic patients targeting cardiovascular diseases.

\section{Abbreviations}

ACh: Acetylcholine; CBSF: Crocodile blood soluble fraction;

DHE: Dihydroethidium; EDR: Endothelium-dependent relaxation;
eNOS: Endothelial nitric oxide synthase; L-NAME: L-N ${ }^{G}$-nitro-L-arginine methyl ester; mBMECs: Mouse brain microvascular endothelial cells; NO: Nitric oxide; PBS: Phosphate-buffered saline; Phe: Phenylephrine; qPCR: Quantitative polymerase chain reaction; ROS: Reactive oxygen species; SNP: Sodium nitroprusside

\section{Supplementary Information}

The online version contains supplementary material available at https://doi. org/10.1186/s43014-021-00066-w.

Additional file 1: Supplementary Figure 1. Crocodile blood does not cause toxicity to C57BL/6 J mice and mBMECs. Body weight (A), and nonfasting blood glucose level (B) of C57BL/6 J mice treated with different doses of crocodile blood via oral gavage for 5 weeks $(n=5)$. Effects of CBSF on the cell viability of mBMECs assessed by XTT Assay $(n=8)(C)$. Data are represented in means \pm SEM. CBSF, crocodile blood soluble fraction; $\mathrm{mBMECs}$, mouse brain microvascular endothelial cells.

\section{Acknowledgements}

Not applicable.

\section{Authors' contributions}

Conceptualization, W.T. Wong; methodology, C.Y. Chook, F.M. Chen; investigation, C.Y. Chook; formal analysis, C.Y. Chook; writing-original draft preparation, C.Y. Chook; writing-review and editing, F.M. Chen, F.P. Leung, C.Y. Chook, G. Tse \& W.T. Wong; visualization, C.Y. Chook; supervision, W.T. Wong. The author(s) read and approved the final manuscript.

\section{Funding}

This study was supported by the Hong Kong Research Grants Council Grant ECS [24163117]; GRF [14101119]; National Natural Science Foundation of China [81970423]; and SKLA (CUHK).

\section{Availability of data and materials}

The data used to support the findings of this study are included in the article.

\section{Declarations}

Ethics approval and consent to participate

All animal experiments were undertaken with the approval from the Animal Experimentation Ethics Committee, the Chinese University of Hong Kong (Ref No. 18-243-MIS).

Consent for publication

All authors approved the final version of this manuscript.

\section{Competing interests}

The authors declare no conflict of interest. The funders had no role in the design of the study; in the collection, analyses, or interpretation of data; in the writing of the manuscript, or in the decision to publish the results.

Received: 27 August 2020 Accepted: 12 June 2021

Published online: 03 August 2021

\section{References}

Aree, K., Siruntawineti, J., \& Chaeychomsri, W. (2011). Crocodylus siamensis serum and macrophage phagocytic activity. Journal of the Medical Association of Thailand = Chotmaihet Thangphaet, 94(Suppl 7(May)), S131-S138 http://www. ncbi.nlm.nih.gov/pubmed/22619919.

Azcutia, V., Abu-Taha, M., Romacho, T., Vázquez-Bella, M., Matesanz, N., Luscinskas, F. W..... Peiró, C. (2010). Inflammation determines the pro-adhesive properties of high extracellular D-glucose in human endothelial cells in vitro and rat microvessels in vivo. PLoS One, 5(4), e10091. https://doi.org/10.1371/ journal.pone.0010091.

Barba, F. J., Koubaa, M., do Prado-Silva, L., Orlien, V., \& de Souza Sant'Ana, A. (2017). Mild processing applied to the inactivation of the main foodborne bacterial pathogens: A review. Trends in Food Science and Technology, 66, 2035. https://doi.org/10.1016/j.tifs.2017.05.011 
Chaeychomsri, W. (2015). Effectiveness in the treatment of Iron deficiency anemia in Sprague-Dawley rats using freeze- dried crocodile blood. International Journal of Life Sciences Biotechnology and Pharma Research, 4(1), 42-49.

Chaeychomsri, W., Siruntawineti, J., Chaeychomsri, S., Hengsawadi, D., Cuptapan, Y., \& Rungtaweechai, W. (2013). Successful development and commercialization of freeze-dried crocodile blood product. In The 39th Congress on Science and Technology of Thailand, (pp. 569-576). https://doi. org/10.1017/CBO9781107415324.004.

Chook, C. Y. B., Chen, F. M., Leung, F. P., Chen, Z., \& Wong, W. T. (2021). Potential of crocodile blood as a medication and dietary supplement: A systemic review. In Clinical and Experimental Pharmacology and Physiology, May, 1-16. https://doi.org/10.1111/1440-1681.13524.

Einarson, T. R., Acs, A., Ludwig, C., \& Panton, U. H. (2018). Prevalence of cardiovascular disease in type 2 diabetes: A systematic literature review of scientific evidence from across the world in 2007-2017. Cardiovascular Diabetology, 17(1), 83. https://doi.org/10.1186/s12933-018-0728-6.

Giacco, F., \& Brownlee, M. (2010). Oxidative stress and diabetic complications. Circulation Research, 107(9), 1058-1070. https://doi.org/10.1161/CIRCRESA HA. 110.223545

Hao, J., Li, Y. W., Xie, M. Q., \& Li, A. X. (2012). Molecular cloning, recombinant expression and antibacterial activity analysis of hepcidin from Siamensis crocodile (Crocodylus siamensis). Comparative Biochemistry and Physiology - $B$ Biochemistry and Molecular Biology, 163(3-4), 309-315. https://doi.org/10.101 6/j.cbpb.2012.08.002.

Huang, Y., Chan, F. L., Lau, C.-W. W., Tsang, S.-Y. Y., Chen, Z.-Y. Y., He, G.-W. W., \& Yao, X. (2003). Roles of cyclic AMP and Ca2+-activated K+ channels in endothelium-independent relaxation by urocortin in the rat coronary artery Cardiovascular Research, 57(3), 824-833. https://doi.org/10.1016/50008-6363 (02)00773-3.

Jangpromma, N., Poolperm, N., Pornsri, K., Anwised, P., Kabbua, T., Phosri, S., ... Klaynongsruang, S. (2017). Proteomics profiling and inflammatory factor gene expression in LPS-stimulated RAW 264.7 cells treated with Crocodylus siamensis hemoglobin. Chiang Mai Journal of Science, 44(3), 800-815.

Jangpromma, N., Preecharram, S., Srilert, T., Maijaroen, S., Mahakunakorn, P. Nualkaew, N., ... Klaynongsruang, S. (2016). In vitro and in vivo wound healing properties of plasma and serum from Crocodylus siamensis blood. Journal of Microbiology and Biotechnology, 26(6), 1140-1147. https://doi.org/1 0.4014/jmb.1601.01054

Jangpromma, N., Suttee, K., Phosri, S., Theansungnoen, T., Lueangsakulthai, J., Payoungkiattikun, W. ... Klaynongsruang, S. (2018). Antioxidant properties of Crocodylus siamensis blood components on $\mathrm{H} 2 \mathrm{O} 2$-induced human skin fibroblast cells. Chiang Mai Journal of Science, 45(3), 1359-1371.

Kaiser, N., Sasson, S., Feener, E. P., Boukobza-Vardi, N., Higashi, S., Moller, D. E., ... King, G. L. (1993). Differential regulation of glucose transport and transporters by glucose in vascular endothelial and smooth muscle cells. Diabetes, 42(1), 80-89. https://doi.org/10.2337/diabetes.42.1.80.

Kelly, T. N. (2009). Systematic review: Glucose control and cardiovascular disease in type 2 diabetes. Annals of Internal Medicine, 151(6), 394. https://doi.org/10. 7326/0003-4819-151-6-200909150-00137.

Kim, J. A., Montagnani, M., Kwang, K. K., \& Quon, M. J. (2006). Reciprocal relationships between insulin resistance and endothelial dysfunction: Molecular and pathophysiological mechanisms. Circulation, 113(15), 18881904. https://doi.org/10.1161/CIRCULATIONAHA.105.563213.

Kommanee, J., Phosri, S., Daduang, S., Temsiripong, Y., Dhiravisit, A., \& Thammasirirak, S. (2014). Comparisons of anti-inflammatory activity of crocodile (Crocodylus siamensis) blood extract. Chiang Mai Journal of Science, 41(3), 627-634.

Kommanee, J., Preecharram, S., Daduang, S., Temsiripong, Y., Dhiravisit, A., Yamada, Y., \& Thammasirirak, S. (2012). Antibacterial activity of plasma from crocodile (Crocodylus siamensis) against pathogenic bacteria. Annals of Clinical Microbiology and Antimicrobials, 11(1), 1. https://doi.org/10.1186/14760711-11-22.

Kozlowski, H. N., Lai, E. T. L., Havugimana, P. C., White, C., Emili, A., Sakac, D., ... Branch, D. R. (2016). Extracellular histones identified in crocodile blood inhibit in-vitro HIV-1 infection. Aids, 30(13), 2043-2052. https://doi.org/10.1097/QAD. 0000000000001159

Lafuente, N., Matesanz, N., Azcutia, V., Romacho, T., Nevado, J., Rodríguez-Mañas, L., ... Sánchez-Ferrer, C. F. (2008). The deleterious effect of high concentrations of D-glucose requires pro-inflammatory preconditioning. Journal of Hypertension, 26(3), 478-485. https://doi.org/10.1097/HJH.0b013e32 $82 \mathrm{f3} 31 \mathrm{fb}$.
Lueangsakulthai, J., Phosri, S., Theansungnoen, T., Jangpromma, N., Temsiripong, T., Mckendrick, J. E., ... Klaynongsruang, S. (2018). Novel antioxidant and antiinflammatory peptides from the Siamese crocodile (Crocodylus siamensis) hemoglobin hydrolysate. Biotechnology and Applied Biochemistry, 65(3), 455466. https://doi.org/10.1002/bab.1628.

Maijaroen, S., Jangpromma, N., Daduang, J., \& Klaynongsruang, S. (2018). KT2 and RT2 modified antimicrobial peptides derived from Crocodylus siamensis Leucrocin I show activity against human colon cancer HCT-116 cells. Environmental Toxicology and Pharmacology, 62(July), 164-176. https://doi. org/10.1016/j.etap.2018.07.007.

Maraming, P., Klaynongsruang, S., Boonsiri, P., Maijaroen, S., Daduang, S., Chung, J. G., \& Daduang, J. (2018). Antitumor activity of RT2 peptide derived from crocodile leukocyte peptide on human colon cancer xenografts in nude mice. Environmental Toxicology, 33(9), 972-977. https://doi.org/10.1002/tox.22584.

Merchant, M., Juneau, K., Gemillion, J., Falconi, R., Doucet, A., \& Shirley, M. H. (2011). Characterization of serum phospholipase A2 activity in three diverse species of west African crocodiles. Biochemistry Research International, 2011, 1-7. https://doi.org/10.1155/2011/925012.

Ou, Y., \& Ho, W. S. (2016). Crocodile blood extract induces the apoptosis of lung cancer cells through PTEN activity. Oncology Reports, 36(3), 1457-1466. https://doi.org/10.3892/or.2016.4914.

Pakdeesuwan, A., Araki, T., Daduang, S., Payoungkiattikun, W., Jangpromma, N., \& Klaynongsruang, S. (2017). In vivo wound healing activity of crocodile (Crocodylus siamensis) hemoglobin and evaluation of antibacterial and antioxidant properties of hemoglobin and hemoglobin hydrolysate. Journal of Microbiology and Biotechnology, 27(1), 26-35. https://doi.org/10.4014/jmb.1 603.03046.

Pata, S., Daduang, S., Svasti, J., \& Thammasirirak, S. (2007). Isolation of lysozyme like protein from crocodile leukocyte extract (Crocodylus siamensis). KMITL Science and Technology Journal, 7(S1), 70-85.

Pata, S., Yaraksa, N., Daduang, S., Temsiripong, Y., Svasti, J., Araki, T., \& Thammasirirak, S. (2011). Characterization of the novel antibacterial peptide Leucrocin from crocodile (Crocodylus siamensis) white blood cell extracts. Developmental and Comparative Immunology, 35(5), 545-553. https://doi. org/10.1016/j.dci.2010.12.011.

Patathananone, S., Thammasirirak, S., Daduang, J., Chung, J. G., Temsiripong, Y., \& Daduang, S. (2015). Bioactive compounds from crocodile (Crocodylus siamensis) white blood cells induced apoptotic cell death in HeLa cells. Environmental Toxicology, 31(8), 986-997. https://doi.org/10.1002/tox.22108.

Peiró, C., Lorenzo, Ó., Carraro, R., \& Sánchez-Ferrer, C. F. (2017). IL-1 $\beta$ inhibition in cardiovascular complications associated to diabetes mellitus. Frontiers in Pharmacology, 8(JUN), 1-13. https://doi.org/10.3389/fphar.2017.00363.

Peiró, C., Romacho, T., Azcutia, V., Villalobos, L., Fernández, E., Bolaños, J. P., .. Sánchez-Ferrer, C. F. (2016). Inflammation, glucose, and vascular cell damage: The role of the pentose phosphate pathway. Cardiovascular Diabetology, 15(1), 1-15. https://doi.org/10.1186/s12933-016-0397-2.

Phosri, S., Jangpromma, N., Chang, L. C., Tan, G. T., Wongwiwatthananukit, S., Maijaroen, S., ... Klaynongsruang, S. (2018). Siamese crocodile white blood cell extract inhibits cell proliferation and promotes autophagy in multiple cancer cell lines. Journal of Microbiology and Biotechnology, 28(6), 1007-1021. https://doi.org/10.4014/jmb.1712.12002.

Phosri, S., Jangpromma, N., Patramanon, R., Kongyingyoes, B., Mahakunakorn, P., \& Klaynongsruang, S. (2017). Protective effect of crocodile hemoglobin and whole blood against hydrogen peroxide-induced oxidative damage in human lung fibroblasts (MRC-5) and inflammation in mice. Inflammation, 40(1), 205-220. https://doi.org/10.1007/s10753-016-0471-7.

Phosri, S., Mahakunakorn, P., Lueangsakulthai, J., Jangpromma, N., Swatsitang, P., Daduang, S., ... Thammasirirak, S. (2014). An investigation of antioxidant and anti-inflammatory activities from blood components of crocodile (Crocodylus siamensis). Protein Journal, 33(5), 484-492. https://doi.org/10.1007/s10930-0149581-y.

Phupiewkham, W., Lu, Q., Payoungkiattikun, W., Temsiripong, T., Jangpromma, N., Lai, R., \& Klaynongsruang, S. (2018). Development and characterization of an anti-acne gel containing siamese crocodile (Crocodylus siamensis) leukocyte extract. Journal of Microbiology and Biotechnology, 28(5), 707-717. https://doi. org/10.4014/jmb.1802.02027.

Preecharram, S., Jearranaiprepame, P., Daduang, S., Temsiripong, Y., Somdee, T., Fukamizo, T., ... Thammasirirak, S. (2010). Isolation and characterisation of crocosin, an antibacterial compound from crocodile (Crocodylus siamensis) plasma. Animal Science Journal, 81(3), 393-401. https://doi.org/10.1111/j.17400929.2010.00752.x. 
Saeedi, P., Petersohn, I., Salpea, P., Malanda, B., Karuranga, S., Unwin, N., ... Williams, R. (2019). Global and regional diabetes prevalence estimates for 2019 and projections for 2030 and 2045: Results from the International Diabetes Federation Diabetes Atlas, 9th edition. Diabetes Research and Clinical Practice, 157, 107843. https://doi.org/10.1016/j.diabres.2019.107843.

Smith, E. (2019, April 13). Expert urges NT to explore use of crocodile compounds in medical industry. ABC News. https://www.abc.net.au/news/2019-04-13/ crocodile-blood-oil-bacteria-antibiotics-antibacterial-medicine/10985546

Sprague, A. H., \& Khalil, R. A. (2009). Inflammatory cytokines in vascular dysfunction and vascular disease. Biochemical Pharmacology, 78(6), 539-552. https://doi.org/10.1016/.jbcp.2009.04.029.

Tabit, C. E., Chung, W. B., Hamburg, N. M., \& Vita, J. A. (2010). Endothelial dysfunction in diabetes mellitus: Molecular mechanisms and clinical implications. Reviews in Endocrine and Metabolic Disorders, 11(1), 61-74. https://doi.org/10.1007/s11154-010-9134-4.

Theansungnoen, T., Yaraksa, N., Daduang, S., Dhiravisit, A., \& Thammasirirak, S. (2014). Purification and characterization of antioxidant peptides from leukocyte extract of Crocodylus siamensis. Protein Journal, 33(1), 24-31. https://doi.org/10.1007/s10930-013-9536-8.

Tian, X. Y., Wong, W. T., Xu, A., Lu, Y., Zhang, Y., Wang, L., ... Huang, Y. (2012). Uncoupling protein-2 protects endothelial function in diet-induced obese mice. Circulation Research, 110(9), 1211-1216. https://doi.org/10.1161/ CIRCRESAHA.111.262170.

Turnbull, F. M., Abraira, C., Anderson, R. J., Byington, R. P., Chalmers, J. P. Duckworth, W. C., ... Woodward, M. (2009). Intensive glucose control and macrovascular outcomes in type 2 diabetes. Diabetologia, 52(11), 2288-2298. https://doi.org/10.1007/s00125-009-1470-0.

Unger, U., Poelsler, G., Modrof, J., \& Kreil, T. R. (2009). Virus inactivation during the freeze-drying processes as used for the manufacture of plasma-derived medicinal products. Transfusion, 49(9), 1924-1930. https://doi.org/10.1111/j.1 537-2995.2009.02218.x.

Vallejo, S., Palacios, E., Romacho, T., Villalobos, L., Peiró, C., \& Sánchez-Ferrer, C. F. (2010). The interleukin-1 receptor antagonist anakinra improves endothelial dysfunction in streptozotocin-induced diabetic rats cardio VASCULAR DIABETOLOGY. Chemico-Biological Interactions, 188(1), 237-245. https://doi. org/10.1186/s12933-014-0158-z.

Versari, D., Daghini, E., Virdis, A., Ghiadoni, L., \& Taddei, S. (2009). Endothelial dysfunction as a target for prevention of cardiovascular disease. Diabetes Care, 32(suppl_2), S314-S321. https://doi.org/10.2337/dc09-S330.

Widlansky, M. E., Gokce, N., Keaney, J. F., \& Vita, J. A. (2003). The clinical implications of endothelial dysfunction. Journal of the American College of Cardiology, 42(7), 1149-1160. https://doi.org/10.1016/50735-1097(03)00994-X.

Xu, S., Yin, M., Koroleva, M., Mastrangelo, M. A., Zhang, W., Bai, P., ... Jin, Z. G. (2017). SIRT6 protects against endothelial dysfunction and atherosclerosis in mice. Aging, 8(5), 1064-1078. https://doi.org/10.18632/aging.100975.

\section{Publisher's Note}

Springer Nature remains neutral with regard to jurisdictional claims in published maps and institutional affiliations.

Ready to submit your research? Choose BMC and benefit from:

- fast, convenient online submission

- thorough peer review by experienced researchers in your field

- rapid publication on acceptance

- support for research data, including large and complex data types

- gold Open Access which fosters wider collaboration and increased citations

- maximum visibility for your research: over $100 \mathrm{M}$ website views per year

At BMC, research is always in progress.

Learn more biomedcentral.com/submissions 